\title{
The Boulder Magnetic Observatory
}

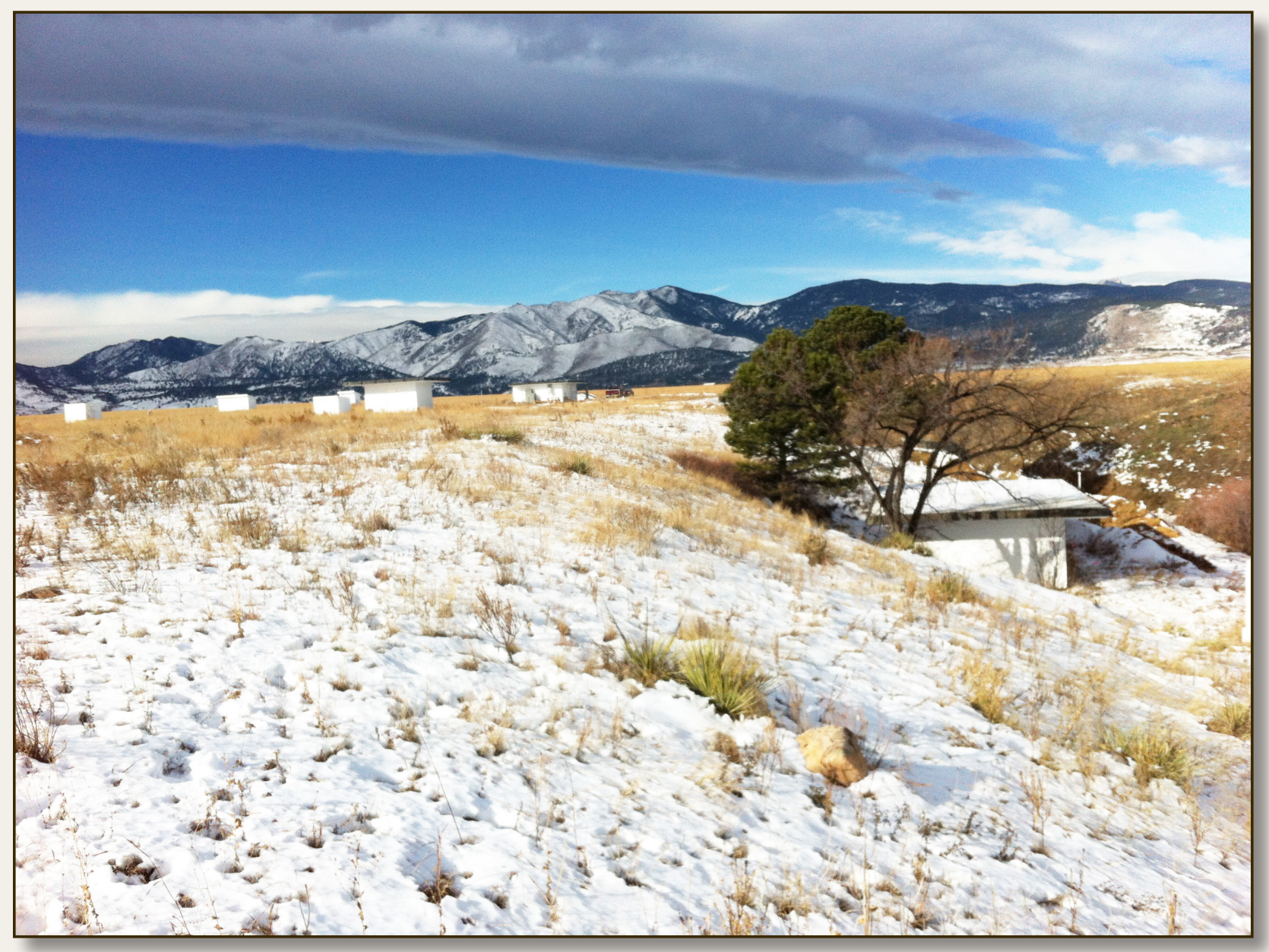

Open-File Report 2015-1125 



\section{The Boulder Magnetic Observatory}

By Jeffrey J. Love, Carol A. Finn, Kolby L. Pedrie, and Cletus C. Blum

Open-File Report 2015-1125

U.S. Department of the Interior

U.S. Geological Survey 


\title{
U.S. Department of the Interior SALLY JEWELL, Secretary
}

\section{U.S. Geological Survey \\ Suzette M. Kimball, Acting Director}

\author{
U.S. Geological Survey, Reston, Virginia: 2015
}

For more information on the USGS - the Federal source for science about the Earth, its natural and living resources, natural hazards, and the environment—visit http://www.usgs.gov or call 1-888-ASK-USGS.

For an overview of USGS information products, including maps, imagery, and publications, visit http://www.usgs.gov/pubprod/.

Any use of trade, firm, or product names is for descriptive purposes only and does not imply endorsement by the U.S. Government.

Although this information product, for the most part, is in the public domain, it also may contain copyrighted materials as noted in the text. Permission to reproduce copyrighted items must be secured from the copyright owner.

Suggested citation:

Love, J.J., Finn, C.A., Pedrie, K.L., and Blum, C.C., 2015, The Boulder magnetic observatory: U.S. Geological Survey Open-File Report 2015-1125, 8 p., http://dx.doi.org/10.3133/ofr20151125.

ISSN 2331-1258 (online) 


\section{Contents}

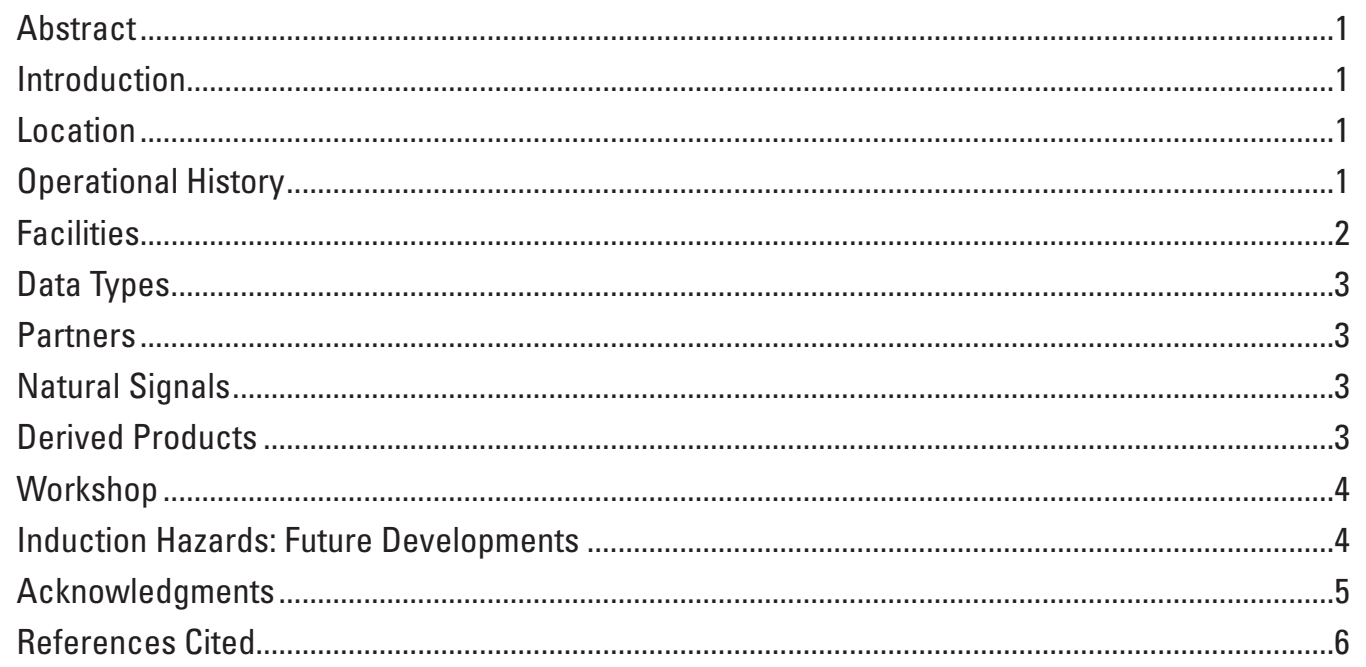

\section{Figures}

1. Aerial view of the USGS Boulder magnetic observatory site ............................................

2-4. Graphs showing:

2. Boulder geomagnetic data for years 1967-2013 ...................................................

3. Quiet time Boulder geomagnetic variation for November 17-22, $2008 \ldots \ldots \ldots \ldots \ldots \ldots \ldots . . .5$

4. Magnetic storm Boulder geomagnetic variation for October 29-31, 2003 ................6 



\title{
The Boulder Magnetic Observatory
}

\author{
Jeffrey J. Love, Carol A. Finn, Kolby L. Pedrie, Cletus C. Blum
}

\section{Abstract}

The Boulder magnetic observatory has, since 1963, been operated by the Geomagnetism Program of the U.S. Geological Survey in accordance with Bureau and national priorities. Data from the observatory are used for a wide variety of scientific purposes, both pure and applied. The observatory also supports developmental projects within the Geomagnetism Program and collaborative projects with allied geophysical agencies.

\section{Introduction}

The Boulder observatory is one of 14 magnetic observatories operated across the United States and Territories by the Geomagnetism Program of the U.S. Geological Survey (USGS) (Love and others, 2008). Along with the other observatories in the Program's network, the Boulder observatory is operated in accordance with strategic goals for geophysical observation established for the USGS Hazards Mission Area (Holmes and others, 2013), in support of the interagency U.S. National Space Weather Program (NSWP, 2010), and as a service to the scientific community (Love, 2008; Love and Finn, 2011).

Magnetometer data from the USGS observatory network have high time resolution, accuracy, and continuity. These properties mean that the data are useful for a wide variety of research and operational applications (Love, 2008), including (1) analysis and mapping of the main field generated in the Earth's deep interior, (2) analysis and real-time monitoring of magnetic variation generated by dynamic conditions in the Earth's space weather environment, (3) assessment and mitigation of magnetic storm interference and hazards for the activities and infrastructure of our technologically based society (Love and Finn, 2011).

Because the Boulder observatory is relatively close to the USGS Geomagnetism Program headquarters in Golden, Colorado, the site is used by Geomagnetism Program engineers and technical staff to develop, calibrate, and test new sensors, acquisition systems, and operational procedures (for example, Worthington and others, 2009; White and others, 2014). The observatory supports allied geophysical measurement systems, and it is used for training Program staff and visiting technicians. In all of these respects, then, the Boulder observatory plays a critical role in supporting the entire mission of the USGS Geomagnetism Program.

\section{Location}

The Boulder observatory is located on what is known as the Table Mountain Field Site, a flat-top butte composed of young Quaternary alluvium north of the city of Boulder, Colorado, just east of the Rocky Mountains $\left(40.1375^{\circ} \mathrm{N}, 105.2372^{\circ} \mathrm{W}\right), 1,682$ meters $(\mathrm{m})$ above sea level (Green, 1992). The land immediately surrounding the observatory is rocky and interspersed with grass and cactus. The climate is semiarid with an average annual temperature of about 11 degrees Celsius. The average annual precipitation is 47 centimeters, often coming in the form of summer thunderstorms and winter snowfall. Although the USGS owns the observatory infrastructure and is responsible for observatory operations within a $1,000-\mathrm{ft}(305-\mathrm{m})$ radius circle centered on the electronics building (discussed below), the land itself is owned by the National Telecommunications and Information Administration (NTIA) of the United States Department of Commerce (DOC).

\section{Operational History}

The history of the Boulder observatory can be traced back to September 1960, when the National Bureau of Standards (NBS) of the DOC constructed a nonmagnetic building for data acquisition on its main campus site in the city of Boulder. Magnetic measurement using photographic analog systems commenced in December 1960. At that time, the Coast and Geodetic Survey (C\&GS) of the DOC was responsible for the operation of several magnetic observatories in the United States. Under terms of an April 15, 1963 memorandum of understanding, magnetic measurement operations were transferred from NBS (1963) to C\&GS. The first reported hourly mean data from the Boulder observatory are in the archives of the World Data Center in Kyoto, Japan. These data were derived from analog magnetograms for April 1963, and, thus, operations at the Boulder observatory commenced in time to contribute to the International Year of the Quiet Sun of 1964. The first published geomagnetic measurements made on the present site of the Boulder observatory, at Table Mountain, were made on July 16, 1964.

On July 13, 1965, the C\&GS was consolidated into the Environmental Science Services Administration of the DOC, which, subsequently, became the National Oceanic and Atmospheric Administration (NOAA) on October 3, 1970. A memorandum of understanding effective on May 27, 1973, 
transferred ownership and operational responsibility of most U.S. magnetic observatories, including the observatory at Boulder, from NOAA (DOC) to USGS of the Department of the Interior (DOI).

The first published 1-minute data values from Boulder are for March 1978. These were made using digital acquisition systems. The 1-minute digital data values represent a substantial improvement in temporal resolution over 1-hour analog data values. Boulder observatory data for the year 1991 contributed to the first joint certification and publication of 1-minute data by the international consortium of magnetic observatory institutes known as INTERMAGNET (Love and Chulliat, 2013). Since June 13, 2011, Boulder 1-second data have been reported to INTERMAGNET. Since 1991, dataacquisition operations at Boulder have been maintained with approximately 97 percent continuity.

\section{Facilities}

The Boulder observatory consists of several small buildings; these serve a variety of functions, and many of them are made of nonmagnetic material; see figure 1. For magnetic measurement operations, the variations building houses a fluxgate magnetometer and a backup fluxgate magnetometer, each maintained at a stable operating temperature. Near this, an Overhauser proton-precession magnetometer is housed in a small hut. The electronics building contains data display computers, network connections, and office space. For review of observatory instrumentation see Rasson (2007).

The Boulder absolutes building houses a specially designed theodolite made of nonmagnetic material and having a small magnetometer attached to its telescope. This instrument is commonly referred to as a declination-inclination magnetometer (DIM). It is situated on a stable pier that serves as a reference point for the entire observatory. The observatory site has several azimuthal reference markers, also on stable piers, and whose orientation relative to the theodolite pier have been carefully measured using geodetic methods.

A coil system, used for testing and calibrating acquisition systems, is housed in its own dedicated building on the Boulder site (White and others, 2008); a separate building houses modern coil-control electronic systems and power supplies. Two cubical buildings are used for testing new sensor and acquisition systems. A storage building is located about $200 \mathrm{~m}$ from the operational and testing buildings.

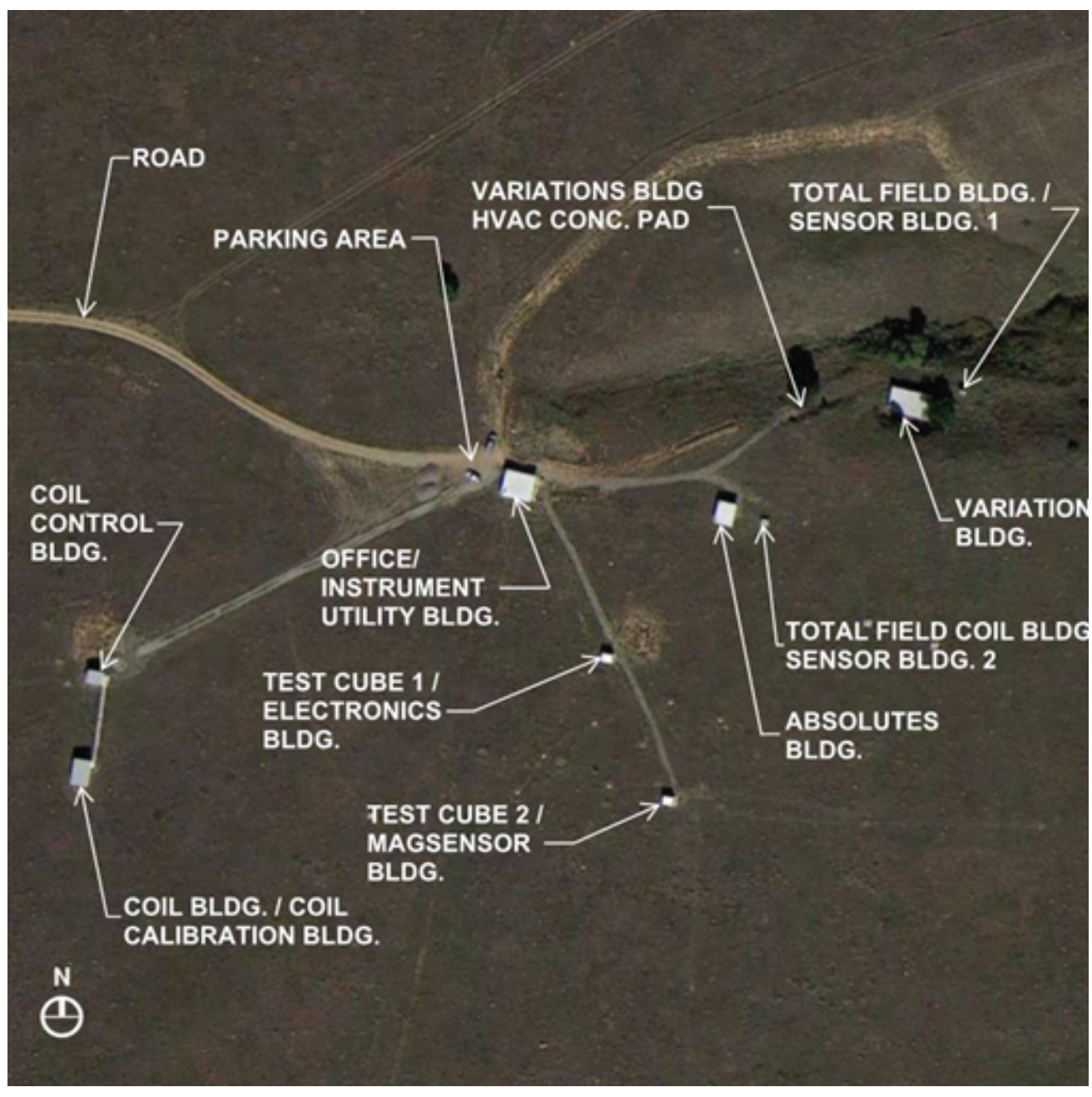

Figure 1. Aerial view of the USGS Boulder magnetic observatory site. (Conc., concrete; Bldg., building) 


\section{Data Types}

Continuous second-to-second change, or "variation," in the geomagnetic field is measured at the Boulder observatory with a fluxgate magnetometer (for example, Primdal, 1979; Narod and Bennest, 1990). These data are sufficient for many applications, such as monitoring geomagnetic space weather phenomena evolving over timescales of a few hours or less. Variation data are available to the user community in real-time as a preliminary data product from both the USGS Geomagnetism Program and INTERMAGNET.

For many applications, however, magnetic variation needs to be defined relative to an accurate baseline. Two different sensors provide accurate auxiliary data. An Overhauser magnetometer (for example, Hrvoic and Hollyer, 2005) provides continuous absolute magnetic field intensity data, and the DIM instrument is used by an observatory worker twice a week or so to make visual measurements of absolute field direction. These auxiliary data are combined with the variometer data through computer-based processing to produce calibrated data (for example, Jankowski and Sucksdorff, 1996). Promptly processed data, known as "quasi-definitive," are available to the user community within a few months of preliminary data acquisition.

Final "definitive" data, an accurate representation of the Earth's magnetic field at the Boulder site, are reported to INTERMAGNET and made available to the user community on an annual schedule. Long-term archives of definitive observatory data are maintained in the World Data System.

\section{Partners}

The USGS Geomagnetism Program collaborates with the University of Washington by supporting the operation of a very low frequency (VLF) (3-30 kilohertz) band antenna on the Boulder observatory site for the World Wide Lightning Location Network (WWLLN; Lay and others 2004). The WWLLN is a collaboration between universities and government labs from around the world for collecting lightninggenerated VLF electric field waveform signals. These are used to estimate the location and time of lightning strikes around the world, in real time.

\section{Natural Signals}

A long-term view of Boulder observatory magnetic field data is provided in figure 2, for years 1967-2013. Here, annual mean values (green) of horizontal intensity $(H)$, declination $(D)$, and the vertical component $(Z)$ of the magnetic field exhibit a slow secular drift. This variation is global in scale and driven by fluid convection in the Earth's core. Note that in the 46 years of time represented in figure 2, declination has changed by about 4 degrees at Boulder.

Relatively more rapid variation of the Boulder geomagnetic field is seen in figure 2 as the variance of hourly mean values (black) about the slower secular variation. This variation occurs in two distinctively different ways: quiet time variation and magnetic-storm variation. Periodic variation in the geomagnetic field is easily seen in observatory data when magnetic conditions are relatively quiet (for example, Owolabi and others, 2014). Electric currents in the Earth's electrically conducting day-side ionosphere are generated by thermospheric winds that are, themselves, driven by day-night differential solar heating. In figure 3 , we show an example of solar-quiet variation recorded in Boulder 1-minute data, November 17-22, 2008; note the prominent quasi-diurnal signal in each of the magnetic field components.

Magnetic storms are caused by the dynamic interaction of the solar wind with the Earth's magnetosphere. In observatory data, storms are seen as a distinctive transient variation. In figure 4 we show Boulder data recording the Halloween storm of October 29-31, 2003 (for example, Gopalswamy and others, 2005). This storm caused operational stress in the Swedish (Pulkkinen and others, 2005) and Scottish power grids (Thomson and others, 2005). The storm commenced with the arrival at Earth of a coronal mass ejection, which abruptly compressed the magnetopause and generated the positive impulse seen in Boulder $Z$ at 06:13 UT on October 29. Complex geomagnetic variation was driven by the arrival of additional coronal mass ejections, solar wind variability, and vigorous magnetospheric convection. What followed was storm main-phase intensification of magnetic activity that lasted for more than 2 days.

\section{Derived Products}

Data from the Boulder observatory are used by NOAA's Space Weather Prediction Center (SWPC) for real-time assessment of mid-continental geomagnetic conditions within the United States (for example, Balch and others, 2004). Boulder observatory data contribute to the U.S. Air Force calculation of an American version of the Kp index (Gehred and others, 1995), a traditional measure of global geomagnetic activity that has historically been used for space weather assessment (for example, Mayaud, 1980). The Kyoto World Data Center in Japan uses Boulder data for the calculation of the symmetric (SYM) and asymmetric (ASY) indices (Iyemori and Rao, 1996). These indices represent, respectively, the symmetric and asymmetric parts of the magnetospheric equatorial ring current, both of which are fundamental quantities used for analysis of magnetic storm dynamics. Boulder data are used in the derivation of the International Geomagnetic Reference Field (IGRF), a spherical harmonic model of the main part of the Earth's magnetic field. Widely used for scientific research, navigation, and near-surface magnetic surveys, the 

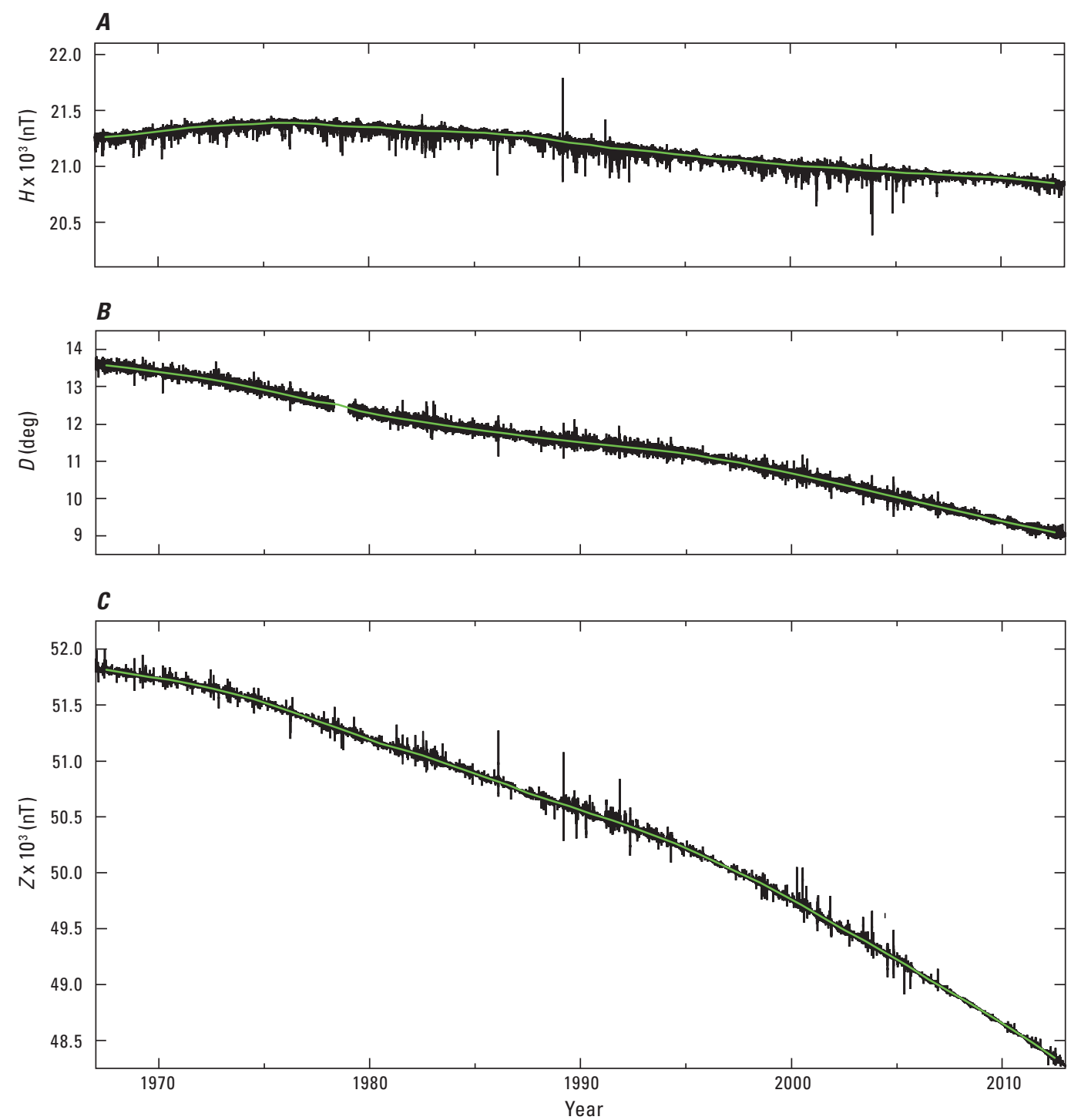

Figure 2. Boulder geomagnetic data for years 1967-2013, hourly values (black) and annual mean variation (green): $A$, horizontal intensity $(H) ; B$, declination $(D)$; and $C$, vertical component (Z). (deg, degrees; $\mathrm{nT}$, nanoTesla)

IGRF is constructed using a combination of data from satellites, ground surveys, and magnetic observatories - including data from the Boulder observatory (for example, Finlay and others, 2010).

\section{Workshop}

The 13th biennial International Association of Geomagnetism and Aeronomy (IAGA) Workshop on Geomagnetic Observatory Instruments, Data Acquisition and Processing was hosted by the USGS Geomagnetism Program, June 9-18, 2008. This was the first time this important workshop was held in the United States. More than 100 participants, representing many different institutions came from 36 countries and 6 continents. In preparation for the workshop, several new absolutes piers were installed at the Boulder observatory to facilitate simultaneous measurement of the absolute direction and intensity of the geomagnetic field (Berarducci and Woods, 2009; White, 2009). Results of the measurement session and the presentations given during the scientific session are presented in the Workshop's proceedings (Love, 2009).

\section{Induction Hazards: Future Developments}

The Boulder observatory has recently become a focal point for the USGS Geomagnetism Program and its support of a multiagency project for studying, monitoring, and evaluating magnetic storm hazards (Love and others, 2014; NSTC, 2015). Of concern is the storm-time induction of geoelectric 

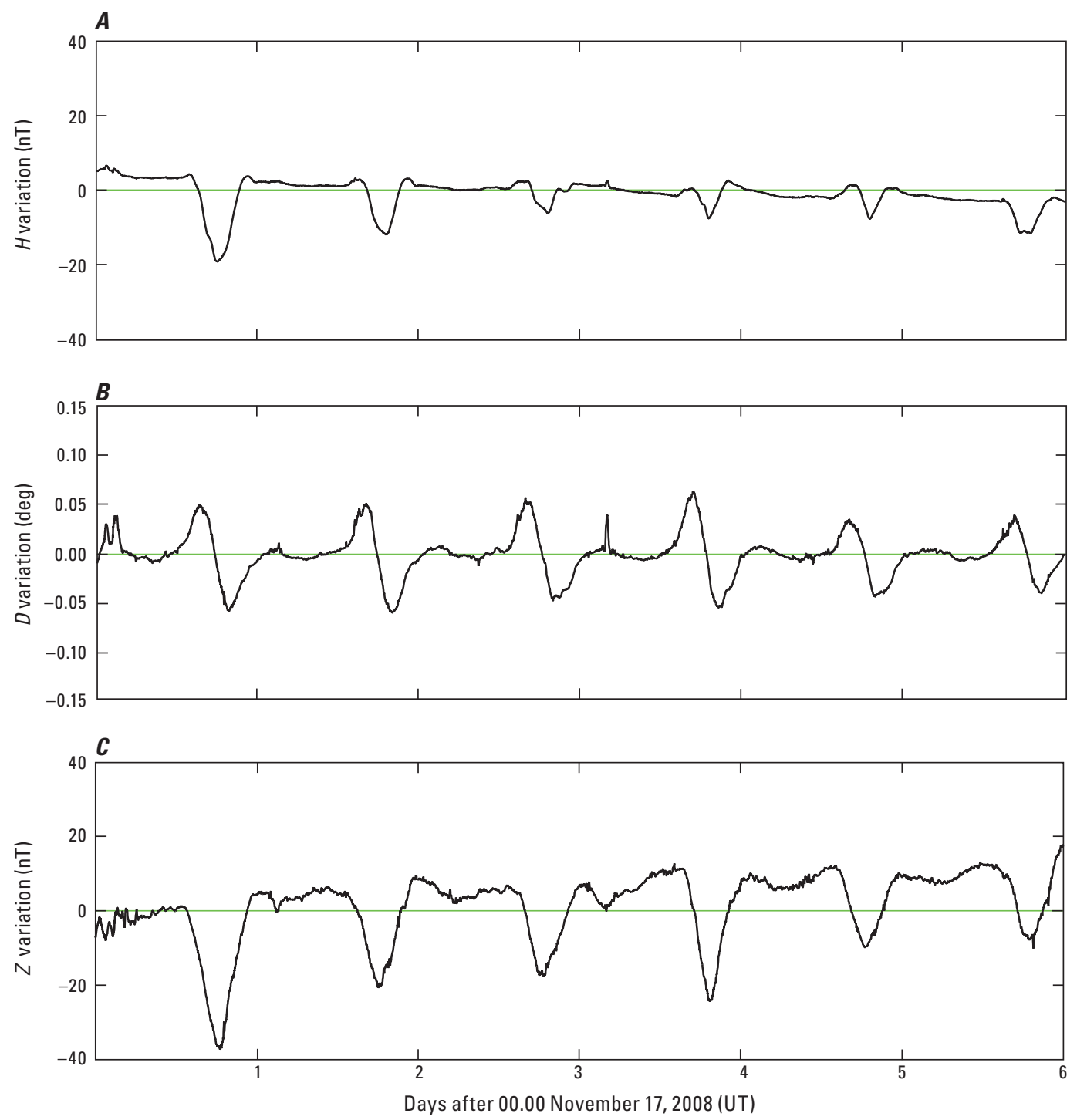

Figure 3. Quiet time Boulder geomagnetic variation for November 17-22, 2008, minute values (black) relative to absolute baseline (green): $A$, horizontal intensity $(H) ; B$, declination $(D)$; and $C$, vertical component (Z). (deg, degrees; nT, nanoTesla)

fields in the Earth's electrically conducting lithosphere. Corresponding voltage differentials can find their way into electric-power grids through ground connections, driving uncontrolled electric currents that interfere with grid operation, sometimes causing blackouts (for example, Boteler and others, 1998).

One part of this induction-hazard project is focused on real-time mapping of storm-time magnetic disturbance across North America using data from the USGS and Canadian observatory networks (Pulkkinen and others, 2003; Rigler and others, 2014). For this, magnetic data from the Boulder observatory, with its location in the continental interior, will play an important role in constructing such maps and validating their accuracy. Another part of the project is focused on estimating the storm-time induction of geoelectric fields, and, as a check of such estimates, the geoelectric field will be directly monitored at the Boulder observatory site.

Other possible operational opportunities for the Boulder observatory include testing electromagnetic crustal exploration systems, and development of a joint U.S.-Canadian calibration facility. In the coming years, the Boulder magnetic observatory will certainly remain an important site for operations and developments within the USGS Geomagnetism Program.

\section{Acknowledgments}

We thank Connor Fisher, Teri Losano, Jill McCarthy, Joy Monson, Melanie Parker, E.J. Rigler, J.L. Slate, T.C. White, and E.W. Worthington for reading a draft manuscript. 

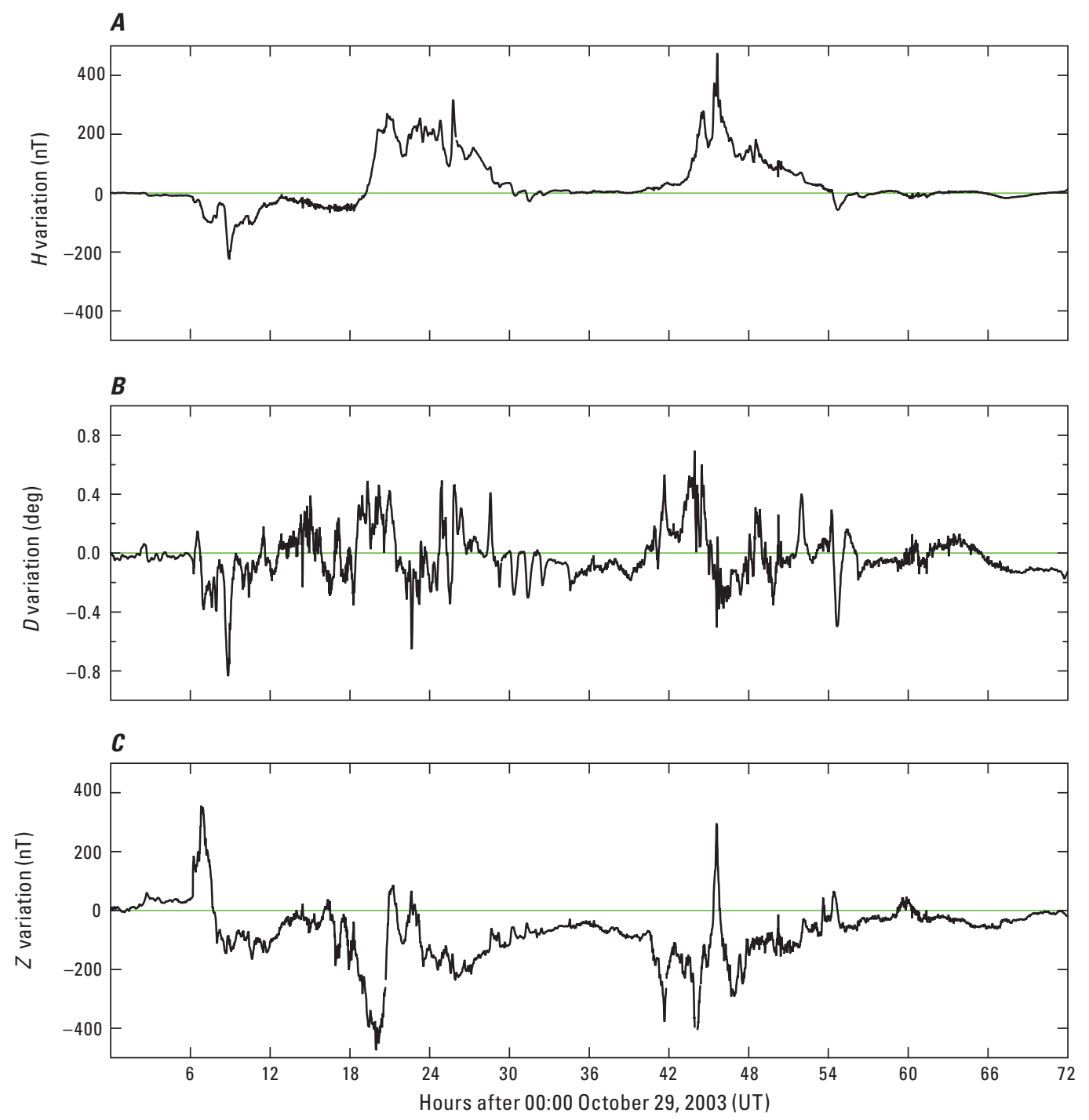

Figure 4. Magnetic storm Boulder geomagnetic variation for October 29-31, 2003, minute values (black) relative to absolute baseline (green): $A$, horizontal intensity $(H) ; B$, declination $(D)$; and $C$, vertical component ( $Z$ ). (deg, degrees; nT, nanoTesla)

\section{References Cited}

Balch, Christopher, Murtagh, Bill, Zezula, David, Combs, Larry, Nelson, Gayle, Tegnell, Ken, Crown, Misty, McGehan, Barbara, 2004, Service assessment, intense space weather storms October 19-November 07, 2003: United States Department of Commerce, National Oceanic and Atmospheric Administration, Silver Spring, Md., 49 p.

Berarducci, Alan and Woods, Andy, 2009, Absolute measurement session, in Proceedings of the XIIIth IAGA Workshop on geomagnetic observatory instruments, data acquisition, and processing (Love, J.J. ed.): U.S. Geological Survey Open-File Report 2009-1226, p. 1-8.

Boteler, D.H., Pirjola, R.J., and Nevanlinna, H., 1998, The effects of geomagnetic disturbances on electrical systems at the Earth's surface: Advances in Space Research, v. 22, p. 17-27.
Finlay, C.C., and others, 2010, International geomagnetic reference field-The eleventh generation: Geophysical Journal International, v. 183, no. 3, p. 1216-1230.

Gehred, P.A., Cliffswallow, W. and Schroeder III, J.D., 1995, A comparison of USAF Ap and Kp indices to Göttingen indices: National Oceanic and Atmospheric Administration, Silver Spring, Md., Technical Memorandum Environmental Research Laboratories SEL-88, 26 p.

Gopalswamy, N., Barbieri, L., Cliver, E.W., Lu, G., Plunkett, S.P. and Skoug, R.M., 2005, Introduction to violent SunEarth connection events of October-November 2003: Journal of Geophysical Research, vol. 110, A09S00, doi:10.1029/2005JA011268.

Green, G.N., 1992, The digital geologic map of Colorado in ARC/INFO Format: U.S. Geological Survey Open-File Report 92-0507, 9 p. 
Holmes, R.R., Jones, L.M., Eidenshink, J.C., Godt, J.W., Kirby, S.H., Love, J.J., Neal, C.A., Plant, N.G., Plunkett, M.L., Weaver, C.S., Wein, Anne and Perry, S.C., 2013, U.S. Geological Survey Natural Hazards Science Strategy-Promoting the Safety, Security, and Economic Well-Being of the Nation: U.S. Geological Survey Circular, 1383-F, 79 p.

Hrvoic, Ivan and Hollyer, G.M., 2005, Brief review of quantum magnetometers: Ontario, Canada, GEM Systems Technical Papers, $15 \mathrm{p}$.

Iyemori, T. and Rao, D.R.K., 1996, Decay of the Dst field of geomagnetic disturbance after substorm onset and its implication to storm-substorm relation: Annales Geophysicae, vol. 14, p. 608-618.

Jankowski, Jerzy, and Sucksdorff, Christian, 1996, Guide for magnetic measurements and observatory practice: Warsaw, Poland, International Association of Geomagnetism and Aeronomy, $235 \mathrm{p}$.

Lay, E.H., Holzworth, R.H., Rodger, C.J., Thomas, J.N., Pinto, O. and Dowden, R.L., 2004, WWLL global lightning detection system - Regional validation study in Brazil: Geophysical Research Letters vol. 31, L03102, doi:10.1029/2003GL018882.

Love, J.J., 2008, Magnetic monitoring of Earth and space: Physics Today, vol. 61, no. 2, p. 31-37.

Love, J.J., Applegate, David and Townshend, J.B., 2008, Monitoring the Earth's dynamic magnetic field: U.S. Geological Survey Fact Sheet 2007-3092.

Love, J.J. (ed.), 2009, Proceedings of the XIIIth IAGA Workshop on geomagnetic observatory instruments, data acquisition, and processing: U.S. Geological Survey Open-File Report 2009-1226, 271 p.

Love, J.J. and Finn, C.A., 2011, The USGS Geomagnetism Program and its role in space weather monitoring: Space Weather, vol. 9, S07001, doi:10.1029/2011SW000684.

Love, J.J. and Chulliat, Arnaud, 2013, An international network of magnetic observatories: Eos Transactions of the American Geophysical Union, vol. 42, p. 373-384, doi:10.1002/2013EO420001.

Love, J.J., Rigler, E.J., Pulkkinen, Antti and Balch, C.C., 2014, Magnetic storms and induction hazards: Eos Transactions of the American Geophysical Union, vol. 95, p. 445-446, doi:10.1002/2014EO480001.

Mayaud, P.N., 1980, Derivation, meaning, and use of geomagnetic indices: American Geophysical Union, Washington, D.C., Geophysical Monograph 22, 154 p.

Narod, B.B. and Bennest, J.R., 1990, Ring-core fluxgate magnetometers for use as observatory variometers: Physics of the Earth and Planetary Interiors, vol. 58, p. 23-28.

NBS, 1963, New geomagnetic observatory: National Bureau of Standards Technical News Bulletin, vol. 47, p. 171.

NSTC, 2015, National space weather strategy: Washington, D.C., Executive Office, National Science and Technology Council, 13 p.
NSWP, 2010, National Space Weather Program strategic plan: Silver Spring, Md., Federal Coordinator for Meteorological Services and Supporting Research, FCM-P30-2010, 24 p.

Owolabi T.P., Rabiu A.B., Olayanju G.M., and Bolaji O.S., 2014, Seasonal variation of worldwide solar quiet of the horizontal magnetic field intensity: Applied Physics Research, vol. 6, p. 82-94, doi:10.5539/apr.v6n2p82.

Primdahl, F., 1979, The fluxgate magnetometer: Journal of Physics E-Scientific Instruments, vol. 12, p. 241-253, doi:10.1088/0022-3735/12/4/001.

Pulkkinen, Antti, Amm, Olaf, Viljanen, Ari, and BEAR Working Group, 2003, Separation of the geomagnetic variation field on the ground into external and internal parts using the spherical elementary current system: Earth Planets and Space, vol. 55, p. 117-129, doi:10.1002/2013SW000990.

Pulkkinen, Antti, Lindahl, Sture, Viljanen, Ari, and Pirjola, Risto, 2005, Geomagnetic storm of 29-31 October 2003Geomagnetically induced currents and their relation to problems in the Swedish high-voltage power transmission system: Space Weather, vol. 3, S08C03, doi:10.1029/2004SW000123.

Rasson, J.L., 2007, Observatories, instrumentation, in Encyclopedia of Geomagnetism and Paleomagnetism (Gubbins, David, and Herrero-Bervera, Emilio, eds.): Springer, p. 711-713.

Rigler, E.J., Balch, C.C., and Wiltberger, M.J., 2014, Dynamic geomagnetic hazard maps in space weather operations, Abstract: Eos Transactions of the American Geophysical Union, vol. 95, SM31A-4178.

Thomson, A.W.P., McKay, A.J., Clarke, Ellen and Reay, S.J., 2005, Surface electric fields and geomagnetically induced currents in the Scottish Power grid during the 30 October 2003 geomagnetic storm: Space Weather, vol. 3, S11002, doi:10.1029/2005SW000156

White, T.C., Sauter, E.A. and Stewart, D.C., 2008, Challenges in the development of the automated coil calibration system at the Boulder Magnetic Observatory, in Proceedings of the XIIIth IAGA Workshop on geomagnetic observatory instruments, data acquisition, and processing, Abstract - Golden, Colo.: U.S. Geological Survey.

White, T.C., 2009, Total field sensor comparison, in Proceedings of the XIIIth IAGA Workshop on geomagnetic observatory instruments, data acquisition, and processing (Love, J.J., ed.): U.S. Geological Survey Open-File Report 2009-1226, p. 9-13.

White, T.C., Sauter, E.A. and Stewart, D.C., 2014, Discovery and analysis of time delay sources in the USGS personal computer data collection platform (PCDCP) system: U.S. Geological Survey Scientific Investigations Report 2014-5045, 24 p.

Worthington, E.W., Sauter, E.A. and Love, J.J., 2009, Analysis of USGS one-second data, in Proceedings of the XIIIth IAGA Workshop on geomagnetic observatory instruments, data acquisition, and processing (Love, J.J., ed.): U.S. Geological Survey Open-File Report 2009-1226, p. 262-267. 
Publishing support provided by:

Denver Publishing Service Center, Denver, Colorado

For more information concerning this publication, contact: USGS Geomagnetism Program

Box 25046, MS 966

Denver, C0 80225-0046

(303) 273-8475

Or visit the Geomagnetism Program Web site at: http://geomag.usgs.gov/

This publication is available online at: http://dx.doi.org/10.3133/ofr20151125 


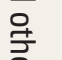

$\frac{1}{\bar{\sigma}}$

맘

혼

产

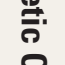

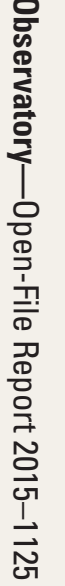

